\title{
ISOLATION, IDENTIFICATION AND BIOACTIVITY SCREENING OF TURKISH MARINE-DERIVED FUNGI
}

\author{
HAJAR HEYDARI ${ }^{1}$, ASLI KOC ${ }^{2}$, DUYGU SIMSEK ${ }^{3}$, BULENT GOZCELIOGLU ${ }^{4}$, NURTEN \\ ALTANLAR $^{3}$, BELMA KONUKLUGIL $^{1 *}$ \\ ${ }^{I}$ Pharmacognosy Department of Ankara University, 06100 Tandoğan, Ankara, Turkey \\ ${ }^{2}$ Biochemistry Department of Ankara University, 06100 Tandoğan, Ankara, Turkey \\ ${ }^{3}$ Pharmaceutical Microbiology Department of Ankara University, 06100 Tandoğan, Ankara, Turkey \\ ${ }^{4}$ Scientific and Technological Research Council of Turkey (TÜBITAK), 06420 Bakanlıklar, Ankara, Turkey \\ *corresponding author: belma.konuklugil@gmail.com
}

Manuscript received: July 2018

\begin{abstract}
Marine-derived fungi are considered as a promising source for discovering new secondary metabolites with pharmaceutical potential. In this study, 18 marine-derived fungi were isolated and identified from marine invertebrates and investigated with regard to their antioxidant, antimicrobial and cytotoxic activities. $\mathrm{DPPH}, \mathrm{SO}, \mathrm{NO}$ and ABTS assays were used for monitoring free radical scavenging activity, and MTT assay was used for cytotoxic activity. For antimicrobial activity determination minimum inhibitory concentration was calculated. As a result, six Penicillium, five Aspergillus, one Alternaria, Cladosporium, Malassezia, Mycosphaerella, Sporobolomyces, Talaromyces and Trichoderma species were isolated from the marine invertebrate. Some of these fungal extracts such as Aspergillus chevalieri has shown high antioxidant and antimicrobial activities, further Aspergillus awamori, Aspergillus niger and Penicillium brevicompactum have shown significant cytotoxic activity against HCT-116 cells. This was the first study about habitant of marine-derived fungi of Turkey's coasts and their antioxidant, antimicrobial and cytotoxicity activities. Besides, it is also the first report about the antioxidant and cytotoxicity activities of C. funiculosum, A. awamori and P. crustosum. Antioxidant and antimicrobial activities of $P$. rubens were reported for the first time in this study.
\end{abstract}

\section{Rezumat}

Ciupercile de origine marină sunt considerate o sursă promițătoare de metaboliți secundari cu potențial farmaceutic. În prezentul studiu sunt descrise 18 ciuperci, izolate și identificate din nevertebrate marine, pentru care a fost studiată activitatea antioxidantă, antimicrobiană și citotoxică. Pentru a demonstra activitatea de chelatare a radicalilor liberi, s-au folosit metodele DPPH, SO, NO și ABTS, iar pentru activitatea citotoxică, metoda MTT. Pentru activitatea microbiană, a fost calculată concentrația minină inhibitorie. Șase specii de Penicillium, cinci Aspergillus, o specie de Alternaria, o specie de Cladosporium, specii de Malassezia, Mycosphaerella, Sporobolomyces, Talaromyces și Trichoderma au fost incluse în studiu. Aspergillus chevalieri a prezentat acțiune antioxidantă și antimicrobiană, în timp ce Aspergillus awamori, Aspergillus niger și Penicillium brevicompactum au prezentat activitate citotoxică pe linia celulară HCT-116. Studiul de față aduce noi informații privind activitatea citotoxică și antioxidantă ale speciilor C. funiculosum, A. awamori și P. crustosum, precum şi asupra activității antioxidante și antimicrobiene a speciei $P$. rubens.

Keywords: antimicrobial activity, antioxidant, cytotoxic activity, marine-derived fungi, Penicillium, Aspergillus

\section{Introduction}

About $70 \%$ of the earth surface is covered by seas and oceans and their different habitats with extreme pressure, changing levels of salinity and temperature give rise to an enormous source of biodiversity [1]. Marine derived microbial communities due to their extensive genetic, biochemical diversity and wide range of bioactivities including antibacterial, antifungal [2, 3], antidiabetic [4], anti-inflammatory [5], antiprotozoal [6], anti-tuberculosis [7], antiviral [8], antitumor, and cytotoxic activities [9] have become a leading hotspot for the discovery of new pharmaceutically active compounds. According to the literature, there are 530 fungal species in 321 genera, among them
424 strains belonging to Ascomycota and 94 strains belonging to anamorphic division [10]. Marine-derived fungi which usually do not cause serious damage to the hosts (Coral, sponge, tunicate and etc.) colonize the internal tissues of their hosts harmoniously and produce a wide range of secondary metabolites such as polyketides, terpenes, peptides and compounds of mixed biosynthesis [11].

Antioxidants are agents which protect cells against the deleterious effects of reactive oxygen species that cause degenerative diseases such as aging, cancer, heart dysfunction and Alzheimer's disease. Marine derived fungi are rich sources of potential antioxidant secondary metabolites $[12,13]$. 
FARMACIA, 2019, Vol. 67, 5

Infectious diseases claim numerous lives worldwide every year, and many of these infections are caused by multi-resistant microorganisms. According to extensive research, some natural compounds from marine-derived fungi have the potential to be used in clinical trials [14].

According to the latest global census in 2012, there was an estimate of 14.1 million new cancer cases. Some secondary metabolites from marine-derived fungi such as aldehydes, alkaloids and nitrogencontaining heterocycles, chromones, cyclohexanones have cytotoxic effects. These natural compounds and their analogues are promising in a new era of cancer treatment [15].

The intent of this study was to provide an overview of the isolation and identification of marine-derived fungi from marine invertebrates and to evaluate their antimicrobial, antioxidant and cytotoxicity activities. It is the first study about Turkish marine- derived fungi and their bioactivity.

\section{Materials and Methods}

\section{Materials}

General

1,1-Diphenyl-2-picryl-hydrazyl (DPPH), 2,2'Azino-bis(3-ethylbenzothiazoline-6-sulfonic acid) diammonium (ABTS), $( \pm$ )-6-hydroxy-2,5,7,8-tetramethylchromane-2-carboxylic acid (Trolox), ascorbic acid, quercetin, 3-(4,5-dimethyl-2-thiazolyl)-2,5-diphenyl-2H-terazoliumbromide (MTT), sulfanilamide, napthylethylenediamine dihydrochloride and sea salts were purchased from Sigma Aldrich, USA Sabouraud 4\% dextrose agar, Muller Hinton broth,
Sabouraud dextrose broth and ethyl acetate was purchased from Merck. RPMI 1640 medium, foetal bovine serum (FBS), streptomycin and glutamine were from PAA (PAsching, Austaria), HCT 116 colon cancer cells were kindly provided by Bert Vogelstein. Nutrient agar was prepared from Oxide. Biospeedy ${ }^{\circledR}$ Fungal Diversity Kit was prepared from Bioeksen, Turkey, Biorad CFX Connect was prepared from BioRad Laboratories, USA. For ABI Prism 377 DNA Sequencer, Applied Biosystems, USA was used. Molecular devices Spectra MAX 190 Microplate Reader helps to get absorbance.

Isolation of marine-derived fungi

Marine samples were collected from Turkey's coast. According to the Kjer et al., samples (sponges, corals, tunicate, worm, alga, molluscs and annelid) were collected by scuba diving and were transferred in suitable containers in sea water and isolation process was carried out within the next hours to avoid the growth of ambient bacteria. The samples were cut to approximately $1 \mathrm{~cm} \times 1 \mathrm{~cm}$ and were rinsed three times with sterile water to eliminate adherent surface debris and for surface sterilization it was immersed in $70 \% \mathrm{EtOH}$ ( $\mathrm{vol} / \mathrm{vol}$ ) for $60-120 \mathrm{~s}$. Samples were dried in a sterile cotton cloth and transferred to a Petri dish containing Sabouraud 4\% dextrose agar and artificial sea salt. Petri dishes were kept for $5-7$ daylight at $25^{\circ} \mathrm{C}$. Treated fungi were purified several times until obtaining pure fungi strain. The obtained pure fungi strains were stocked in glycerine at $-80^{\circ} \mathrm{C}$ [16]. The sample information is shown in Table I.

Table I

Obtained fungal strains from marine species

\begin{tabular}{cccc}
\hline Fungus strains & Species & Origin & Location \\
\hline Alternaria alternata & Parazoanthus axinella & Coral & Sinop \\
Aspergillus awamori & Parazoanthus axinella & Sponge & Ayvalik \\
Aspergillus chevalieri & Anthozoa sp. & Coral & Marmara \\
Aspergillus costaricaensis & Hermodice carunculata & Worm & Cirali \\
Aspergillus niger & Microcosmus vulgaris & Tunicate & Saroz \\
Aspergillus terreus & Spirorbis sp. & Annelid & Marmara \\
Cladosporium funiculosum & Clavelina lepadiformis & Tunicate & Ayvalik \\
Malassezia globosa & Halimeda tuna & alga & Ayvalik \\
Mycosphaerella tassiana_1 & Bursatella leachii & Mollusca & Seferihisar \\
Penicillium brevicompactum & Aplysina aerophoba & Sponge & Saroz \\
Penicillium commune & Mytilus galloprovincialis & Mollusca & Sinop \\
Penicillium crustosum & Axinella damicornis & Sponge & Saroz \\
Penicillium griseofulvum & Eudendrium racemosum & Coral & Saroz \\
Penicillium roqueforti & Pyura momus & Tunicate & Cirali \\
Penicillium rubens & Agelas oroides & Sponge & Ayvalik \\
Sporobolomyces carnicolor & Spirorbis sp. & Annelid & Marmara \\
Talaromyces brunneus & Axinella polypoides & Sponge & Marmara \\
Trichoderma harzianum & Parazoanthusaxinella & Sponge & Sinop \\
\hline
\end{tabular}

Identification of Fungi

DNA isolation was performed from fungal cultures using Fungal DNA Isolation Kit. PCR-based Biospeedy ${ }^{\circledR}$ Fungal Diversity Kit was used to determine fungal diversity after spectrophotometric quality checks of the DNA obtained. The kit contains the forward primer (TCCTCCGCTTATTGATATGC) and reverses primer (GGAAGTAAAAGTCGTAACAAGG) pair 
FARMACIA, 2019, Vol. 67, 5

(Schochand Conrad, 2012) and optimized qPCR (Real Time PCR) chemistry specific to the ITS15.8S-ITS2 region in the fungi genomic DNA. All reactions were performed using Biorad CFX Connect qPCR. The device was subjected to an optimized thermal cycle program specific to primer pair and a melting curve analysis between $65^{\circ} \mathrm{C}$ and $95^{\circ} \mathrm{C}$ to determine that only the desired product was amplified during qPCR. qPCR results were analysed in Biorad CFX Connect Software 3.0.

Sequences of the fungal amplicons were determined with ABI Prism Big Dye Terminator Cycle Sequencing Ready Reaction Kit using ABI Prism 377 DNA Sequencer. Sequence obtained for each fungal sample was analysed in Chromas software package version 1.45 .

The sequences were compared with NCBI DNA database ITS regions identified from known fungal species and paired with most similar species. (BLAST). At this step, sequences with similarity $\geq 98 \%$ were considered to belong to the same species [17].

Preparation of marine fungal extracts

Pure fungi strains were cultured on a solid medium to obtain marine-derived fungi extract bioactivity as proposed by Kjer et al. The strains covering the surface of the inoculated Petri dishes were cut into small pieces of $1.5 \mathrm{~cm} \times 1.5 \mathrm{~cm}$ and transferred into $2 \mathrm{~L}$ Erlenmeyer flasks contained sterilized rice and artificial sea salt medium, and were kept for $4-6$ weeks at $25^{\circ} \mathrm{C}$. For extraction, EtOAc was added to the culture medium containing the mycelium, the extracts were filtered and evaporated under vacuum to obtain EtOAc extracts. The crude extracts were kept at $4^{\circ} \mathrm{C}$ until use [16].

Bioactivity screening for fungal extracts

Antimicrobial activity

The stock solutions of sample extracts were prepared in dimethylsulphoxide (DMSO) at a final concentration of $512 \mu \mathrm{g} / \mathrm{mL}$ and were sterilized by using $0.22 \mu \mathrm{m}$ Millipore Membrane Filter (USA). Standard microorganisms for the antimicrobial activity studies were supplied from Department of Pharmaceutical Microbiology, Faculty of Pharmacy, Ankara University. Staphylococcus aureus (ATCC 25923), Staphylococcus aureus (ATCC 43300), Staphylococcus epidermidis (ATCC 35984), Bacillus subtilis (ATCC 6633), Escherichia coli (ATCC 25922), Pseudomonas aeruginosa (ATCC 27853), Klebsiella pneumoniae (RSKK 574), Candida albicans (ATCC 10231) and Candida parapsilosis (ATCC 22019) strains were used for antimicrobial screening. As per the recommendations of CLSI, broth microdilution method was used for the determination of the antibacterial and antifungal activity of these samples extracts [18]. The tested two fold serial dilutions of the extracts were between 256 and $0.5 \mu \mathrm{g} / \mathrm{mL}$. The sealed microplates were placed in a humid chamber and incubated at $35^{\circ} \mathrm{C}$, 24 hours for the bacteria and at $25^{\circ} \mathrm{C}, 48$ hours for yeasts. The lowest concentration of the extract that completely inhibited the growth of the microorganism was accepted as minimum inhibitory concentration (MIC)

Cell Viability Assay

Colon cancer cell line (HCT-116) were grown in RPMI 1640 medium supplemented with $10 \%$ foetal bovine serum, glutamine $(2 \mathrm{mM})$ and $100 \mathrm{U} / \mathrm{mL}$ penicillin and $100 \mu \mathrm{g} / \mathrm{mL}$ streptomycin in a humidified atmosphere of $5 \% \mathrm{CO}_{2}, 95 \%$ air at $37^{\circ} \mathrm{C}$. Trypsinization was used to passage cells. Cytotoxic activity of extracts against HCT-116 colon cancer cells was performed by the 3-(4,5-dimethylthiazol-2-yl)-2,5-diphenyltetrazolium bromide (MTT) test. For this purpose, $\left(2 \times 10^{4}\right.$ cells/well) were seeded to 96 well plates and incubated for $24 \mathrm{~h}$. Then methanolic extracts $(0.1-200 \mu \mathrm{g} / \mathrm{mL})$ were added to the cells and incubated for $24 \mathrm{~h}$. After incubation, MTT reagent $(5 \mathrm{mg} / \mathrm{mL})$ was added to the wells and incubated for $4 \mathrm{~h}$. To dissolve the formazan crystals, DMSO was added and the absorbance was measured at 550 $\mathrm{nm}$ using microplate reader (Thermo Scientific). GraphPad Prism 7.0 software (GraphPad Software, USA) was used to calculate the $\mathrm{IC}_{50}$ values [19].

DPPH Antioxidant Activity Determination

The stock solution of DPPH was prepared freshly in methanol $(0.1 \mathrm{mM})$. Different concentrations of EtOAc extracts in different concentrations were added to an equal volume to methanolic DPPH solution. After $30 \mathrm{~min}$ at room temperature, the absorbance was recorded at $517 \mathrm{~nm}$. Ascorbic acid and quercetin were used as standards [20]. Radical scavenging activity was calculated by the following formula:

$$
\begin{aligned}
\text { Inhibition } \%= & {\left[\left(\text { Absorbance }_{\text {control }}-\text { Absorbance }_{\text {sample }}\right) /\right.} \\
& \text { Absorbance } \left._{\text {control }}\right] \times 100 .
\end{aligned}
$$

\section{ABTS ${ }^{++}$Antioxidant Activity Determination}

$\mathrm{ABTS}^{++}$stock solution was prepared by mixing 7.4 $\mathrm{mM} \mathrm{ABTS}^{++}$solution and $2.6 \mathrm{mM}$ potassium persulfate solution, the obtained solution was allowed to react for $12-16 \mathrm{~h}$ at room temperature in the dark. The solution was then diluted by mixing $\mathrm{ABTS}^{++}$ solution and methanol to obtain an absorbance of $0.7 \pm 0.02$ units at $734 \mathrm{~nm}$. In a final volume of $300 \mu \mathrm{L}$, the reaction mixture comprised $275 \mu \mathrm{L}$ of $\mathrm{ABTS}^{++}$ solution were added to $25 \mu \mathrm{L}$ of the EtOAc extract at various concentrations. Absorbances of these solutions were measured spectrophotometrically at $734 \mathrm{~nm}$ [21]. Radical scavenging activity was calculated by the following formula:

$$
\begin{gathered}
\text { Inhibition } \%=\left[\left(\text { Absorbance }_{\text {control }}-\text { Absorbance }_{\text {sample }}\right) /\right. \\
\text { Absorbance } \left._{\text {control }}\right] \times 100 .
\end{gathered}
$$

The $\mathrm{IC}_{50}$ were obtained through extrapolation from a regression analysis. The antioxidant activity was evaluated based on this $\mathrm{IC}_{50}$ value.

The antioxidant potential of the EtOAc extracts also was quantified by reference to a Trolox standard 
FARMACIA, 2019, Vol. 67, 5

calibration curve. The calibration curve is linear in the range 0.01 to $0.125 \mathrm{mM}$ for Trolox, with an equation of $y=99.709 x+38.707$ and a correlation coefficient of $\mathrm{r}^{2}=0.9973$.

Superoxide radical scavenging activity by alkaline DMSO method (SO)

Superoxide radical scavenging activity of the extracts were determined by alkaline DMSO method. Briefly, superoxide radical was generated in non-enzymatic system. $1 \mathrm{~mL}$ of alkaline DMSO $(5 \mathrm{mM} \mathrm{NaOH}$ in 0.1 $\mathrm{mL}$ water) was added to $10 \mu \mathrm{L}$ of NBT $(1 \mathrm{mg} / \mathrm{mL})$ and $30 \mu \mathrm{L}$ of different concentration of extracts or standard compounds. To the reaction mixture containing solution in DMSO) to give a final volume of $140 \mu \mathrm{L}$. The absorbance was measured at $560 \mathrm{~nm}$ using a microplate reader [22].

Radical scavenging activity was calculated by the following formula:

$$
\begin{aligned}
\text { Inhibition } \%= & {\left[\left(\text { Absorbance }_{\text {control }}-\text { Absorbance }_{\text {sample }}\right) /\right.} \\
& \text { Absorbance } \left._{\text {control }}\right] \times 100
\end{aligned}
$$

The $\mathrm{IC}_{50}$ were obtained through extrapolation from the regression analysis. The antioxidant activity was evaluated based on this $\mathrm{IC}_{50}$ value.

Nitric oxide radical scavenging activity (NO)

$\mathrm{NO}$ radical scavenging activity of extracts was determined. Brifley, $60 \mu \mathrm{L}$ of sodium nitroprusside $(10 \mathrm{mM})$ dissolved in phosphate buffered saline was added to $60 \mu \mathrm{L}$ of serially diluted extracts and incubated under light at room temperature for 150 min. Finally, an equal volume of Griess reagent
(1\% sulfanilamide, $0.1 \%$ napthylethylenediamine dihydrochloride, $2.5 \% \mathrm{H}_{3} \mathrm{PO}_{4}$ ) was added into each well in order to measure the nitrite content. Absorbance at $577 \mathrm{~nm}$ was measured in a microplate reader after the formation of chromofore at room temperature in $10 \min [23]$.

Radical scavenging activity was calculated with the following formula:

Inhibition $\%=\left[\left(\right.\right.$ Absorbance $_{\text {control }}-$ Absorbance $\left._{\text {sample }}\right) /$
Absorbance
control $] \times 100$

The $\mathrm{IC}_{50}$ were obtained through extrapolation from a regression analysis. The antioxidant activity was evaluated based on this $\mathrm{IC}_{50}$ value.

\section{Results and Discussion}

Marine species listed in Table I were collected from different coasts of Turkey. Six Penicillium, five Aspergillus, one Alternaria, Cladosporium, Malassezia, Mycosphaerella, Sporobolomyces, Talaromyces and Trichoderma species were isolated. EtOAc extracts were obtained and prepared from fungi used for bioactivity tests. Antioxidant activity of extracts was determined by DPPH, ABTS, NO and SO assays. According to the obtained results A.chevalieri and $A$. terreus showed high antioxidant activity in all four assays. On the other hand, A. awamori, M. globose, M. tassiana_1 and T. harzianum showed the lowest activity. The results are presented in Table II.

Table II

\begin{tabular}{|c|c|c|c|c|c|}
\hline \multirow[b]{2}{*}{ Fungi Extracts } & \multirow{2}{*}{$\begin{array}{c}\text { DPPH } \\
\mathrm{IC}_{50}(\mu \mathrm{g} / \mathrm{mL}) \\
\pm \mathrm{SD}\end{array}$} & \multirow{2}{*}{$\begin{array}{c}\mathrm{SO} \\
\mathrm{IC}_{50}(\mu \mathrm{g} / \mathrm{mL}) \\
\pm \mathrm{SD}\end{array}$} & \multirow{2}{*}{$\begin{array}{c}\text { NO } \\
\mathrm{IC}_{50}(\mu \mathrm{g} / \mathrm{mL}) \\
\pm \mathrm{SD}\end{array}$} & \multicolumn{2}{|c|}{ ABTS } \\
\hline & & & & $\begin{array}{c}\mathrm{IC}_{50}(\mu \mathrm{g} / \mathrm{mL}) \\
\pm \mathrm{SD}\end{array}$ & $\begin{array}{c}\text { TEAC } \\
\left(\mathrm{mM}_{\text {Trolox }} / \mathrm{mg}_{\text {Extract }}\right)\end{array}$ \\
\hline Alternaria alternata & $6294.6 \pm 2.1$ & $3303.45 \pm 1.1$ & $3539.72 \pm 0.96$ & $2877.18 \pm 1.68$ & $0.0258 \pm 1.68$ \\
\hline Aspergillus awamori & $>20000$ & $15811.35 \pm 0,99$ & $3393.1 \pm 1.98$ & $2344.28 \pm 1.6$ & $0.0184 \pm 1.6$ \\
\hline Aspergillus chevalieri & $9.04 \pm 1.50$ & $109.38 \pm 3.8$ & $250.59 \pm 1.01$ & $109.64 \pm 0.73$ & $1.17 \pm 0.73$ \\
\hline Aspergillus costaricaensis & $456.0 \pm 1.24$ & $330.34 \pm 1.1$ & $397.16 \pm 0.89$ & $194.98 \pm 1.76$ & $0.3044 \pm 1.76$ \\
\hline Aspergillus niger & $42.3 \pm 1.56$ & $1545,14 \pm 0.99$ & $1617.96 \pm 0.79$ & $676.08 \pm 1.36$ & $0.1804 \pm 1.36$ \\
\hline Aspergillus terreus & $8.07 \pm 1.12$ & $46.66 \pm 1.5$ & $82.97 \pm 1.77$ & $56.23 \pm 0.86$ & $1.44 \pm 0.86$ \\
\hline Cladosporium funiculosum & $5874.4 \pm 1.36$ & $3971.64 \pm 0.87$ & $4255.38 \pm 1.54$ & $5011.78 \pm 1.62$ & $0.0266 \pm 1.62$ \\
\hline Malassezia globosa & $868.9 \pm 1.73$ & $548.23 \pm 1.25$ & $629.46 \pm 0.29$ & $741.31 \pm 1.07$ & $0.0183 \pm 1.07$ \\
\hline Mycosphaerella tassiana_1 & $>20000$ & $9098.5 \pm 1.98$ & $1172.11 \pm 0.69$ & $1548.16 \pm 1.49$ & $0.0146 \pm 1.49$ \\
\hline Penicillium brevicompactum & $222.55 \pm 1.09$ & $4255.6 \pm 0.77$ & $4456.25 \pm 1.2$ & $1862.08 \pm 1.46$ & $0.023 \pm 1.46$ \\
\hline Penicillium commune & $42.35 \pm 1.66$ & $370.65 \pm 0.87$ & $466.62 \pm 0.98$ & $398.1 \pm 1.35$ & $0.397 \pm 1.35$ \\
\hline Penicillium crustosum & $125 \pm 1.24$ & $868.9 \pm 0.14$ & $952.73 \pm 0.96$ & $831.76 \pm 1.36$ & $0.042 \pm 1.36$ \\
\hline Penicillium & $189.19 \pm 1.80$ & $1285.15 \pm 0.89$ & $1545.14 \pm 0.39$ & $1122.01 \pm 1.49$ & $0.105 \pm 1,49$ \\
\hline Penicillium roqueforti & $126.12 \pm 1.89$ & $810.9 \pm 1.5$ & $909.85 \pm 1.65$ & $1002.11 \pm 1.15$ & $0.0808 \pm 1.15$ \\
\hline Penicillium rubens & $377.49 \pm 1.90$ & $2084.3 \pm 0.36$ & $1733.68 \pm 0.88$ & $2754.22 \pm 1.05$ & $0.0272 \pm 1.05$ \\
\hline Sporobolomyces carnicolor & $497.63 \pm 1.49$ & $756.78 \pm 0.87$ & $931.04 \pm 1.09$ & $1479.1 \pm 1.5$ & $0.0259 \pm 1.5$ \\
\hline Talaromyces brunneus & $392.78 \pm 1.39$ & $706.26 \pm 0.77$ & $868.9 \pm 2.11$ & $1174.89 \pm 1.42$ & $0.21 \pm 1.42$ \\
\hline Trichoderma harzianum & $601.13 \pm 1.82$ & $599.7 \pm 0.98$ & $810.9 \pm 1.2$ & $933.25 \pm 1.17$ & $0.0185 \pm 1.17$ \\
\hline Ascorbic acid & $5.72 \pm 0.89$ & $8.52 \pm 0.78$ & $10.12 \pm 0.19$ & $8.21 \pm 0.91$ & - \\
\hline Quercetin & $7.04 \pm 0.94$ & $10.11 \pm 0.28$ & $13.18 \pm 0.15$ & $11.1 \pm 0.23$ & - \\
\hline
\end{tabular}

Antioxidant activity of fungal extracts

Cytotoxicity activity of these extracts was carried out by using the MTT assay against HCT 116 cells. As shown in Table III, A. awamori, P. brevicompactum and $A$. niger showed the highest growth inhibition effect against HCT-116 cells where camptothecin was used as a positive standard drug. 
FARMACIA, 2019, Vol. 67, 5

\section{Table III}

In vitro cytotoxic activity of fungal extracts

\begin{tabular}{lc}
\hline \multicolumn{1}{c}{ Fungi Extract } & IC $_{\mathbf{5 0}}(\boldsymbol{\mu g} / \mathbf{m L}) \pm \mathbf{S D}$ \\
\hline Alternaria alternata & $28.194 \pm 2.81$ \\
Aspergillus awamori & $3.13 \pm 0.58$ \\
Aspergillus chevalieri & $32.38 \pm 5.6$ \\
Aspergillus costaricaensis & $12.03 \pm 1.04$ \\
Aspergillus niger & $4.428 \pm 0.60$ \\
Aspergillus terreus & $99.054 \pm 7.36$ \\
Cladosporium funiculosum & $157.45 \pm 6.77$ \\
Malassezia globosa & $102.70 \pm 7.68$ \\
Mycosphaerella tassiana_1 & $20.002 \pm 1.589$ \\
Penicillium brevicompactum & $6.55 \pm 1.03$ \\
Penicillium commune & $182.98 \pm 5.25$ \\
Penicillium crustosum & $104.60 \pm 7.02$ \\
Penicillium griseofulvum & $19.98 \pm 1.17$ \\
Penicillium roqueforti & $13.075 \pm 1.85$ \\
Penicillium rubens & $48.46 \pm 6.52$ \\
Sporobolomyces carnicolor & $>200$ \\
Talaromyces brunneus & $165.12 \pm 9.51$ \\
Trichoderma harzianum & $53.78 \pm 9.14$ \\
Camptothecin & $0.305 \pm 0.078$ \\
\hline
\end{tabular}

Antimicrobial activity of fungal extracts was tested against Gram positive and Gram negative bacterial strains and against yeasts; the results are presented in Table IV. A.chevalieri, A. niger, M. tassiana_1, $S$. carnicolor were shown to have higher antibacterial activity than the other fungi extracts when tested against Gram positive bacterial strains. On the other hand, $P$. griseofulvum showed higher antibacterial activity than the other fungal extracts tested against Gram negative bacteria. $P$. roqueforti and $P$. brevicompactum were more effective than other fungal extracts against tested yeasts.

A number of studies on antimicrobial activity of $A$. awamori as well as its secondary metabolites have been reported until now. Among the isolated compounds (1,4-Dimethoxybenzene, emodin and 3, 6-dibenzylpiperazine-2,5-dione) only emodin was active against Staphyloccocus aureus and Bacillus subtilis (MIC: $16 \mu \mathrm{g} / \mathrm{mL}$ and $32 \mu \mathrm{g} / \mathrm{mL}$ respectively) and has also showed high antimicrobial activity against Enterococcus faecalis and $A$. niger (MIC: 125 and $85 \mu \mathrm{g} / \mathrm{mL}$, respectively) [24]. In similar studies on the crude extract of $A$. awamori at a concentration of $200 \mu \mathrm{g} / \mathrm{mL}$ also showed high antimicrobial activity against Candida rugose and Escherichia coli (zone diameter: 16 and $24 \mathrm{~mm}$ respectively) [25]. In this study, the EtOAc extract of $A$. awamori was shown significant cytotoxic activity against $\mathrm{HCT} 116$ cells $\left(\mathrm{IC}_{50}: 3.13 \pm 0.58 \mu \mathrm{g} / \mathrm{mL}\right)$, but showed no significant antimicrobial and antioxidant activity.

According to the previous studies, 2-carboxymethyl3-n-hexyl maleic acid and 2-methylene-3-hexylbutanedioic acid which were isolated from $A$. niger have germination inhibitory effect on plants [26]. In another study, crude extract of $A$. niger showed antimicrobial activity against Escherichia coli and
Pseudomonas fluorescens (18 and $6 \mathrm{~mm}$ zone inhibition) [27]. In our study the crude extract of $A$. niger was shown to have significant cytotoxic activity against HCT 116 cells $\left(\mathrm{IC}_{50}: 4.428 \pm 0.60 \mu \mathrm{g} / \mathrm{mL}\right.$ ) and moderate antibacterial activity against Gram positive bacteria, especially against $B$. subtilis (MIC: $62.5 \mu \mathrm{g} / \mathrm{mL}$ ). A. niger, besides these two bioactivities, has shown high radical scavenging activity.

According to the studies, mycophenolic acid was isolated from $P$. brevicompactum to be responsible for the antimicrobial activity of this fungi $[28,29]$. The EtOAc extract of $P$. revicompactum which was found to be effective especially against $S$. epidermidis and B. subtilis (MIC: $31.25 \mu \mathrm{g} / \mathrm{mL}$ ) showed moderate antioxidant and cytotoxic effect.

Previous studies show, antibacterial activity of $P$. crustosum extracts without and with $\beta$-lactamase was reported $16.6 \pm 1.1$ and $21 \pm 1.0 \mathrm{~mm}$ inhibition against Micrococcus luteus respectively [30]. According to the literature survey, phenylpyropene A, B and C isolated from $P$. griseofulvum and these compounds showed cholesterol acyltransferase inhibitor effect [31]. In our study, P. griseofulvum and P. crustosum showed antibacterial activity, especially against $S$. epidermidis (MIC: $31.25 \mu \mathrm{g} / \mathrm{mL}$ ) and B.subtilis (MIC: $31.25 \mu \mathrm{g} / \mathrm{mL}$ ) respectively.

Aspergillus species are, widely distributed in nature and the species of this genus have a great ecological and medical importance. They are thought to be the highest producers of bioactive secondary metabolites. Up to now, there are a lot of studies on bioactive secondary metabolites. In a study by Coudhary et $a l$, there were tested the bioactivities of secondary metabolites isolated from A. terreus. They found that 6-(4'-hydroxy-2'-methyl phenoxy) - (-) - (3R) mellein and (3R, 4R) -6,7-dimethoxy-4-hydroxyiminene showed significant antifungal activity against human pathogens. In the same study, 6-(4'-hydroxy2'-methyl phenoxy) - (-) - (3R) -melle was also found to have strong antioxidant activity [32].

According to the literature survey, forty seven bioactive compounds were identified by GC-MS in the methanolic extract of $A$. terreus and volatile compounds of $A$. terreus were highly effective to suppress the growth of Streptococcus pneumoniae [33]. In this study, we investigated the ethyl acetate extracts of $A$. terreus in terms of antimicrobial, cytotoxic and antioxidant activity. These fungal species were found to be active only against Candida parapsilosa $(250 \mu \mathrm{g} / \mathrm{mL})$. In addition to this activity, it was found that the fungi examined showed high antioxidant activity and moderate cytotoxicity activity. Bladt et al., isolated chloctanspirone A from $P$. rubens this compound was shown activity against HL-60 and A-549 cell lines [34]. In our study, $P$. rubens extract has shown moderate antioxidant and cytotoxicity activity, but it was not active against tested microbial strains. 
Table IV

Antimicrobial activity of fungal extracts MIC $(\mu \mathrm{g} / \mu \mathrm{L})$

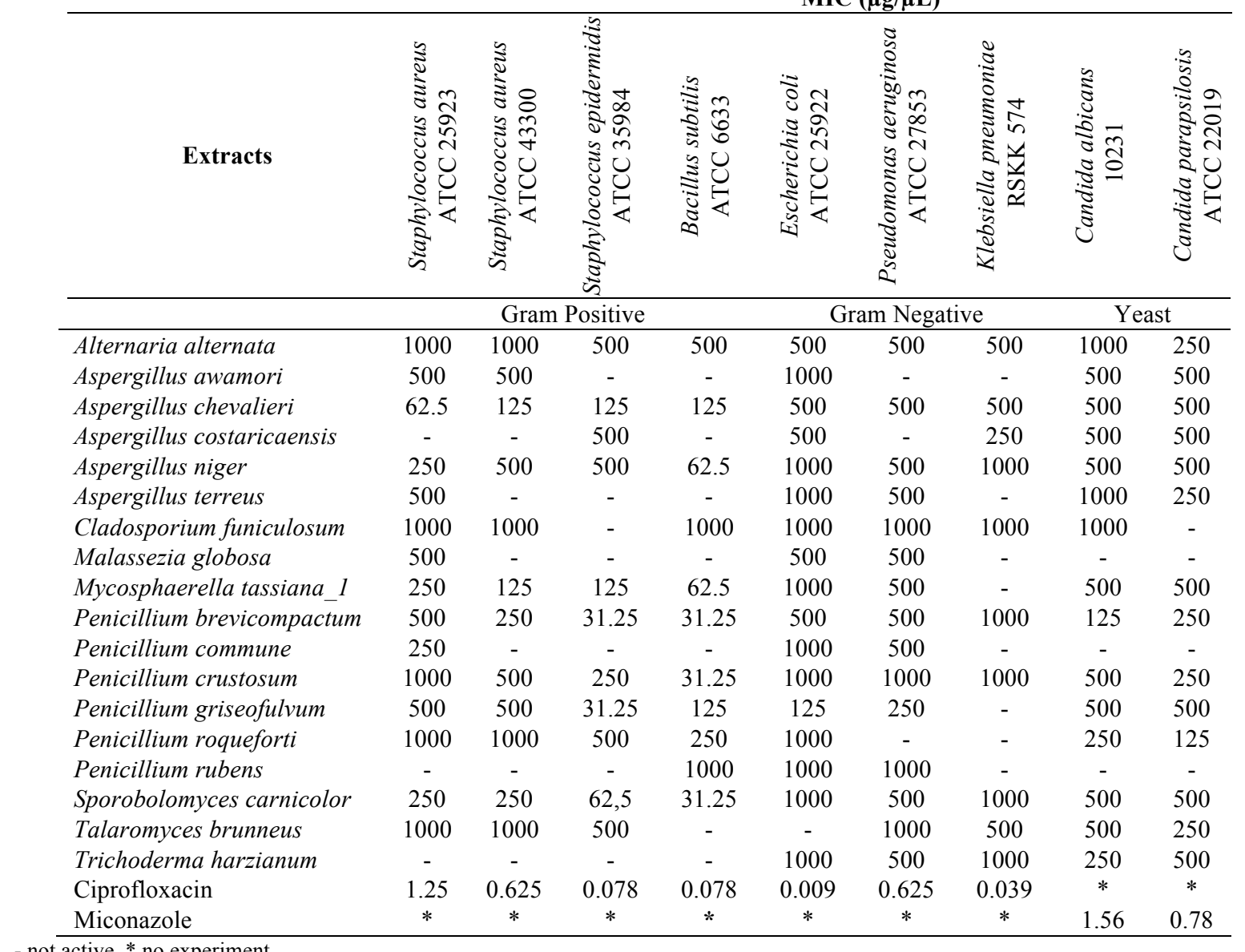

Isophomenone and 3-deacetylcitreohybridonol were isolated from $P$. commune, and tested against Bacillus subtilis, Candida albicans, Pseudomonas aeruginosa, Pseudomonas fluorescens, and methicillin resistant Staphylococcus aureus, but none of them displayed notable activity [35]. In the other study by Shang et al., xanthocillin $\mathrm{X}$, which is a known antibacterial compound and three steroids, two ceramides, six aromatic compounds and three alkaloids were isolated from $P$. commune. In the bioassay, xanthocillin $\mathrm{X}$ displayed significant antimicrobial activity against Staphylococcus aureus and Escherichia coli, and cytotoxicity against MCF-7, HepG2, H460, Hela, Du145, and MDA-MB-231 cell lines. Meleagrin, one of the alkaloids that was isolated from $P$. commune exhibited cytotoxicity against HepG2, Hela, Du145, and MDA-MB-231 cell lines [36].

Several studies have been reported on the bioactivity of Alternaria species as well as their secondary metabolites. Twenty six bioactive compounds were identified in methanolic extract of $A$. alternata by GC Mass. The antimicrobial activity of the extract has shown inhibition $(5.04 \pm 0.29 \mathrm{~mm})$ against Klebsiella pneumoniae [37]. In a study by Fernandes et al., the total phenol content $(3.44 \mathrm{GAE} / \mathrm{mg})$ and antimicrobial effect of the crude extract of $A$. alternata was examined. As a result, it was found that the extract was active against $S$. aureus and $E$. coli (MIC: $50-100 \mu \mathrm{g} / \mathrm{mL}$ and $400-800 \mu \mathrm{g} / \mathrm{mL}$ ) but not against $C$. albicans. In addition, the DPPH assay showed no antioxidant effect, antitumor activity was determined by the MTT assay against HeTa cell lines $(400 \mu \mathrm{g} / \mathrm{mL})$ [38]. According to the previous studies, Secondary metabolites from Alternaria sp. cyclohexenone derivative, cyclopentenone derivative exhibited potent ABTS scavenging activities. Two xanthone derivatives and fischexanthone from Alternaria sp. also showed antimicrobial activity [39]. In the other study by Wang et al., alternariol isolated from A. alternata was active against Bacillus subtilis $\left(\mathrm{MIC}_{80}: 8.6 \mu \mathrm{g} / \mathrm{mL}\right)$ and alternariol 9-methyl ether showed mild cytotoxic activity against U2OS cell lines $\left(\mathrm{IC}_{50}: 28.3 \mu \mathrm{M}\right)[40]$. According to the results obtained in this study, A. alternata extract has shown weak antimicrobial and moderate antioxidant and cytotoxicity activity.

In the study which carried out by Silvia- Hughes et al., C. funiculosum has shown antifungal activity against Candida fragariae, Candida gloeosporioides and Candida acutatum [41]. Brefeldin A, ethyl 2,4- 
FARMACIA, 2019, Vol. 67, 5

dihydroxy-5,6-dimethylbenzoate and phomopsilactone that was isolated by Singh et al., from Cladosporium species have shown strong antifungal activity and also Cladosporium sp. extract was screened for antibacterial test against E. coli, B. subtilis, $S$. aureus. The zones of inhibition ranged from $14-37 \mathrm{~mm}$ [42]. In the previous studies, T22 azaphilone and harzianopyridone isolated from $T$. harzianum showed significant antifungal activity [43, 44]. In present study $C$. funiculosum and $T$. harzianum extracts were shown weak antioxidant, antimicrobial and cytotoxicity activity.

In this study we found that, some of the marine derived-Turkish fungi extracts such as A. awamori, $A$. niger and $P$. brevicompactum have shown high cytotoxic activity against HCT 116 cell lines $\left(\mathrm{IC}_{50}\right.$ : $3.13 \pm 0.58,4.428 \pm 0.60$ and $7.43 \pm 2.1 \mu \mathrm{g} / \mathrm{mL}$ respectively). The highest antioxidant activity belonged to $A$. chevalieri and A. terreus extracts containing ftavoglaucin and this compound was reported to exert antioxidant activity [45].

\section{Conclusions}

In conclusion, in this study 18 fungi were isolated from marine species collected from Turkish coasts. According to the results of the study, six Penicillium, five Aspergillus, one Alternaria, Cladosporium, Malassezia, Mycosphaerella, Sporobolomyces, Talaromyces and Trichoderma species were isolated. This study is a preview study to discover more active fungi species and will serve as guidance for future studies. Some of these fungi extracts displayed significant antioxidant, antimicrobial and cytotoxicity activity. For instance, $A$. chevalieri was the most active fungi against the tested microbial organism and showed high antioxidant activity. Likewise, $A$. awamori was the most effective fungi against HTC 116 cell lines. This is the first study about habitant of marine-derived fungi of Turkey's coasts and their antioxidant, antimicrobial and cytotoxicity activity. Besides, it is also the first report about antioxidant and cytotoxicity activity of $C$. funiculosum, A. awamori and P. crustosum. In addition of these results antioxidant and antimicrobial activity of $P$. rubens was reported for the first time in this study. Consequently, these extracts originated from the marine derived fungi sources need further investigation with a view to identify the active components that could be developed as potential drugs to be used against diseases threatening human health. This type of studies may help our understanding of the fungal diversity in various marine habitats with different biological activity.

\section{Conflict of interest}

The authors declare no conflicts of interest. All the experiments were undertaken in this study comply with the current laws of the country where they were performed.

\section{Acknowledgement}

This study was supported, in part, by The Scientific and Technological Research Council of Turkey (TÜBİTAK), Project No: BMBF114S916.

\section{References}

1. Elnaggar MS, Ebrahim W, Mandi A, Kurtan T, Muller WDE, Kalscheuer R, Singab A, Lin W, Liu $Z$, Proksch P, Hydroquinone derivatives from the marine-derived fungus Gliomastix sp. RSC Advance, 2017; 7(49): 30640-30649.

2. Christophersen C, Crescente, O, Frisvad JC, Gram L, Nielsen J, Nielsen PH, Rahbek L, Antibacterial activity of marine-derived fungi. Mycopathologia, 1998; 143: 135-138.

3. Xu L, Meng W, Cao C, Wang J, Shan W, Wang Q, Antibacterial and antifungal compounds from marine fungi. Mar Drug, 2015; 13(6): 3479-3513

4. El-Hady FKA, Abdel-Aziz MS, Abdou AM, Shaker KH, Ibrahim LS, El-Shahid ZA, In vitro anti-diabetic and cytotoxic effect of the coral derived fungus (Emericella unguis 8429) on human colon, liver, breast and cervical carcinoma cell lines. Int J Pharm Sci Rev Res., 2014; 27(2): 296-301.

5. Shin HJ, Pil GP, Heo SJ, Lee HS, Lee JS, Lee YJ, Lee J, Won HS, Anti-inflammatory activity of tanzawaic acid derivatives from a marine-derived fungus Penicillium steckii 108YD142. Mar Drugs, 2016; 14(1): 1-9.

6. Pontius A, Krick A, Kehraus S, Brun R, König GM, Antiprotozoal activities of heterocyclic-substituted xanthones from the marine-derived fungus Chaetomium sp. J Nat Prod., 2008; 71(9): 1579-1584.

7. Luo X, Zhou X, Lin X, Qin X, Zhang T, Wang J, Tu Z, Yang B, Liao S, Tian Y, Pang X, Kaliyaperumal K, Li JL, Tao H, Liu Y, Antituberculosis compounds from a deep-sea-derived fungus Aspergillus sp. Nat Prod Res., 2017; 31: 1958-1962.

8. Moghadamtousi SZ, Nikzad S, Kadir HA, Abubakar S, Zandi K, Potential antiviral agents from marine fungi: An overview. Mar Drugs, 2015; 13(7): 4520-4538.

9. Ramos AA, Preta-Sena M, Castro-Carvalho B, Dethoup T, Buttachon S, Kijjoa A, Rocha E, Potential of four marine-derived fungi extracts as anti-proliferative and cell death-inducing agents in seven human cancer cell lines. Asian Pac J Trop Med., 2015; 8: 798-806.

10. Jones EBG, Sakayaroj J, Suetrong S, Somrithipol S, Pang KL, Classification of marine Ascomycota, anamorphic taxa and Basidiomycota. Fungal Divers, 2009; 35: 1-187.

11. Hasan S, Ansari MI, Ahmad A, Mishra M, Major bioactive metabolites from marine fungi: A Review. Bioinform., 2015; 11(4): 176-181.

12. Abdel-Monem N, Abdel-Azeem AM, Ashry ES, Ghareeb D, Nabil-Adam A, Assessment of secondary metabolites from marine-derived fungi as antioxidant. Open J Med Chem., 2013; 3(3): 60-73. 
FARMACIA, 2019, Vol. 67, 5

13. Ivănescu B, Tuchiluș C, Corciovă A, Lungu C, Mihai CT, Gheldiu AM, Vlase L, Antioxidant, antimicrobial and cytotoxic activity of Tanacetum vulgare, Tanacetum corymbosum and Tanacetum macrophyllum extracts. Farmacia, 2018; 66(2): 282-288.

14. Bajpai VK, Antimicrobial secondary metabolites from marine fungi: A mini review. Indian J Geomarine Sci., 2016; 45(9): 1067-1075.

15. Prata-Sena M, Ramos AA, Buttachon S, CastroCarvalho B, Marques P, Dethoup T, Kijjoa A, Rocha E, Cytotoxic activity of Secondary Metabolites from Marine-derived Fungus Neosartoryasiamensis in Human Cancer Cells. Phytother Res., 2016; 30 (11): 1862-1871.

16. Kjer J, Debbab A, Aly AH, Proksch P, Methods for isolation of marine-derived endophytic fungi and their bioactive secondary products. Nat Protoc., 2010; 5(3): 479-490.

17. Sun Y, Cai Y, Huse SM, Knight R, Farmerie WG, Mai V, A large-scale benchmark study of existing algorithms for taxonomy- independent microbial community analysis. Brief Bioinform., 2011; 13(1): 107- 121.

18. CLSI. Methods for Dilution Antimicrobial Susceptibility Tests f or Bacteria That Grow Aerobically; Approved St andard $9^{\text {th }}$ Edition. CLSI document M07-A9. Wayne, PA: Clinical and Laboratory Standards Institute; 2012.

19. Mosmann T, Rapid colorimetric assay for cellular growth and survival: application to proliferation and cytotoxicity assays. J Immunol Methods., 1983; 65(1-2): 55-63

20. Popescu ML, Costea T, Gîrd CE, Fierăscu I, Balaci TD, Fierăscu RC, Antioxidant activity of Romanian Agaricus blazei Murrill. and Agaricus bisporus J. E. Lange mushrooms. Farmacia, 2017; 65(3): 329-335.

21. Huang $\mathrm{MH}$, Huang SS, Wang BS, Wu CH, Sheu MJ, Hou WC, Lin SS, Huang GJ, Antioxidant and anti-inflammatory properties of Cardiospermum halicacabum and its reference compounds ex vivo and in vivo. J Ethnopharmacol., 2011; 133(2): 743750 .

22. Harput US, Genç Y, Khan N, Saracoglu I, Radical scavenging effects of different Veronica Species. Rec Nat Prod., 2011; 5(2): 100-107.

23. Senthil Kumar R, Rajkapoor B, Perumal P, Antioxidant activities of Indigofera cassioides Rottl. Ex. DC. using various in vitro assay models. Asian Pac J Trop Biomed., 2012; 2(4): 256-261.

24. Chang M, Wang J, Tian F, Zhang Q, Ye B, Antibacterial activity of secondary metabolites from Aspergillus awamori F12 isolated from rhizospheric soil of Rhizophora stylosa Griff. Wei Sheng Wu Xue Bao, 2010; 50: 1385-1391.

25. Swathi J, Narendra K, Sowjanya KM, Satya KA, Evaluation of biologically active molecules isolated from obligate Marine fungi. Mintage J Pharm Med Sci., 2013; 2: 45-47.

26. Mondal G, Dureja P, Sen B, Fungal metabolite from Aspergillus niger AN27 related to plant growth promotion. Indian J Exp Biol., 2000; 38: 84-87.
27. Osamwonyi UO, Waki SM, Isolation of fungal species from fermentating pearl millet gruel and determination of their antagonistic activities against indicator bacterial species. Nigerian Food Journal, 2012, 30(1): 35-42.

28. Bringmann G, Lang G, Steffens S, Schaumann K, Petrosifungins A and B, novel cyclodepsipeptides from a sponge-derived strain of Penicillium brevicompactum. J Nat Prod., 2004; 67 (3): 311315.

29. Nicoletti R, Trincone A, Bioactive compounds produced by strains of Penicillium and Talaromyces of marine origin. Mar Drugs, 2016; 14(2): 1-35.

30. Laich F, Fierro F, Martín JF, Production of Penicillin by fungi growing on food products: Identification of a complete penicillin gene cluster in Penicillium griseofulvum and a truncated cluster in Penicillium verrucosum. Appl Environ Microbiol., 2002; 68(3): 1211-1219.

31. Kwon OE, Rho, MC, Song HY, Lee SW, Chung MY, Lee JH, Kim YH, Lee HS, Kim YK, Phenylpyropene A and B, new inhibitors of acylCoA: cholesterol acyltransferase produced by Penicillium griseofulvum F1959. J Antibiot., 2002; 55(11): 1004-1008.

32. Choudhary MI, Musharraf SG, Mukhmoor T, Shaheen F, Ali S, Rahman A, Isolation of bioactive compounds from Aspergillus terreus. Z Naturforsch., 2004; 59(33): 324-328.

33. Mohammed GJ, Kadhim MJ, Hussein HM, Characterization of bioactive chemical compounds from Aspergillus terreus and evaluation of antibacterial and antifungal activity. Int $J$ Pharmacog Phytochem Res., 2016; 8(8): 889-905.

34. Bladt TT, Frisvad JC, Knudsen PB, Larsen TO, Anticancer and antifungal compounds from Aspergillus, Penicillium and other filamentous fungi. Molecules, 2013; 18(9): 11338-11376.

35. Gao SS, Shang Z, Li XM, Li CS, Cui CM, Wang BG, Secondary metabolites produced by solid fermentation of the marine-derived fungus Penicillium commune QSD-17. Biosci Biotechnol Biochem., 2012; 76(2): 358-360.

36. Shang Z, Li X, Meng L, Huang G, Wang B, Chemical profile of the secondary metabolites produced by a deep-sea sediment-derived fungus Penicillium commune SD-118. Chinese Chin J Oceanol Limnol., 2012; 30(2): 305-314

37. Kamal SA, Hamza LF, Hameed IH, Antibacterial activity of secondary metabolites isolated from Alternaria alternate. Afr J Biotechnol., 2015; 14(43): 2972-2994.

38. Fernandes MRV, Silva TAC, Pfenning LH, CostaNeto CM, Heinrich TA, Alencar SM, Lima MA, Ikegaki M, Biological activities of the fermentation extract of the endophytic fungus Alternaria alternata isolated from Coffea arabica L. Braz J Pharm Sci., 2009; 45(4): 677-685.

39. Wang J, Ding W, Wang R, Du Y, Liu H, Kong X, Li C, Identification and bioactivity of compounds from the mangrove endophytic fungus Alternaria sp. Mar Drug, 2015; 13(7): 4492-4504. 
40. Wang Y, Yang M H, Wang XB, LiTX, Kong LY, Bioactive metabolites from the endophytic fungus Alternaria alternata. Fitoterapia, 2014; 99: 153158.

41. Silva-Hughes AF, Wedge DE, Cantrell CL, Carvalho CR, Pan Z, Moraes RM, Madox VL, Rosa LH, Diversity and antifungal activity of the endophytic fungi associated with the native medicinal cactus Opuntia humifusa (Cactaceae) from the United States. Microbiol Res., 2015; 175: 67-77.

42. Singh A, Luthra U, Saxena RK, Brief review on bioactive metabolites of fungus isolated from soil. Imper J Interdis Res., 2017; 3(2): 1460-1499.

43. Vinale F, Ghisalberti EL, Sivasithamparam K, Marra R, Ritieni A, Ferracane R, Woo S, Lorito M,
Factors affecting the production of Trichoderma harzianum secondary metabolites during the interaction with different plant pathogens. Lett Appl Microbiol., 2009; 48:705-711.

44. Tarus PK, Langat-Thoruwa CC, Wanyonyi AW, Chhabra SC, Bioactive metabolites from Trichoderma Harzianum and Trichoderma Longibrachiatum. Bull Chem Soc Ethiop., 2003; 17: 185-190.

45. Ishikawa $\mathrm{Y}$, Morimoto $\mathrm{K}$, Piamasaki $\mathrm{T}$, Flavoglaucin, a metabolite of Eurotium chevalieri, its antioxidation and synergism with tocopherol. $J$ Am Oil Chem Soc., 1984; 61(12): 1864-1868. 